\title{
THE IMPACT OF AFFORDABLE HOUSING DEVELOPMENTS ON SUSTAINABILITY IN GULF CITIES
}

\author{
Florian Wiedmann, Ashraf M. Salama, and Hatem G. Ibrahim
}

\begin{abstract}
The recent construction boom has led to new urban development dynamics in Gulf cities driven by real-estate speculations and large infrastructure investments. While in the past affordable housing for medium income migrants and their families was integrated within the fringes of old downtown areas and compound developments in the suburbs, recent investment patterns have led to an increasing challenge of these economically highly engaged social groups to find residences. In recent years, a newly emerging trend in the Gulf region has been the establishment of large scale mass housing projects as new dormitory settlements to address the growing demand for affordable housing. This paper presents an overview of current development patterns by exploring two major affordable housing projects and their impact on sustainability in Doha and Dubai This is undertaken by establishing a preliminary assessment framework that involves relevant sustainability parameters. The assessment reveals the major differences between both projects and their impact on environment, economy and society.
\end{abstract}

Keywords: Affordable housing, Gulf, urban qualities, sustainability, urbanism, Doha, Dubai

\section{INTRODUCTION}

Since the industrial revolution the struggle of providing affordable housing to all social groups has been a major urban planning challenge. Modern urban planning itself is thus rooted in the first planning policies for mass housing developments for laborers, such as the five-story "rental barracks" in Berlin, which were a result of the city plan of 1858 (Hall, 2002, p. 33). Historic city cores became surrounded by a fringe of high density housing redefining the previous urban structure. The decreasing urban qualities caused by overcrowded and highly polluted urban areas had a significant influence on the era of urban utopias at the turn of the century. These utopias can be seen from Ebenezer Howard (1902), who envisioned the "Garden City" concept to be based on affordable housing in well-connected villages surrounding the industrial centers and escaping the pollution, to the Swiss-French architect Le Corbusier, who introduced mass housing schemes with large integrated open spaces, which he called "Ville Radieuse (The Radiant City)" (Le Corbusier, 1967). These city visions were accompanied by technological advancement of new and efficient modes of transportation. 
While the development of first tram lines and subways during the 19th century already permitted a rapid increase of urban areas, the mass production of cars and certain public incentives during the first half of the 20th century led to a new urban form shaped by a sprawling low-rise urban periphery in the United States and subsequently worldwide (Jackson, 1985). The escape of middle and higher income groups to the new suburbs led to an increasing social segregation and labor housing was mainly found in proximity to old urban centers and industrial areas (Nightingale, 2012). Various public strategies were launched to integrate social housing in the case of newly developed urban areas. Based on new visions and economic concerns mass housing estates were initiated in geometrical grids, particularly during the 1960s and 1970s, the peak of planning for the "automotive city" (Newman and Kenworthy, 1989). These social housing projects were usually built on the basis of a modular system to safe costs and first residential tower blocks for lower income groups changed urban landscapes (Lund, 1996).

Since the end of the 20th century cities worldwide have gained an increasing importance as main nodal points within an expanding global network of advanced service sectors (Sassen, 1994). The newly emerging knowledge economies led to a new phenomenon, known as gentrification, which has been a direct result of the lifestyle choices of a highly educated workforce and associated urban lifestyles as well as investment flows (David, 1994). Richard Florida (2002) claims that these knowledge workers have had a direct impact on the upgrading process of many downtown areas in Western cities. One inevitable consequence of this tendency has been rising rental rates in recent years and the subsequent move of low to medium income groups towards the urban periphery.

Today, the continuous tendency of investing in central urban areas has led to an emerging need for affordable housing for both low and medium income groups. The result has been various new programs including public-private-partnerships in order to accommodate these large and diverse social groups, who play a key role in enabling economic growth and whose daily commutes are critical for the general energy efficiency of any city. Furthermore, they have an important role in establishing distinctive communities and thus particular urban identities due to their large number and the general diversity of their social structure. Once again the need for affordable housing has begun to transform spatial urban conditions and large scale development sites have been initiated to establish new dormitory settlements instead of introducing intervention schemes to permit the integration of affordable housing in already existing urban areas. Therefore, there is an emerging demand to understand the impact of these mega projects on urban sustainability. In the context of the Gulf region, this paper presents an overview of current development patterns by exploring two major affordable housing projects and their impact on sustainability in Doha and Dubai. Based a preliminary assessment framework major differences between both projects and their impact on environment, economy and society are revealed. 


\section{THE HISTORY OF AFFORDABLE HOUSING IN THE GULF}

When the oil production commenced in the middle of the 20th century public subsidies were needed to supply modern housing standards to local populations in Gulf cities (Scholz, 1999, p. 77). In addition to the distribution of land, mortgages were supported and backed by governments to enable improved housing conditions for locals. The tendency of subdividing new unbuilt land and the expanding infrastructural networks resulted in excessive urban sprawl and the fast spread of suburban dwellings (AI Hathloul and Mughal, 2004). In parallel, the previous settlement areas were demolished and used as main commercial centers and home for low to medium income migrants, who resided in first multi-story apartment buildings as well as low-rise dwellings, some of which still held features of traditional architecture. Migrants with higher income were accommodated in newly built compounds in suburban areas (Salama and Wiedmann, 2013, p. 31).

In general, the housing of a large part of the first migrants was supplied by companies, which rented dwellings and compounds from the newly founded semi-public holdings as well as locals, who became more and more involved as developers and landlords (Al Buainain, 1999, p. 92). This initial setup within the private sector has led to a reduced lack of affordable housing for migrant communities during the 1970s and 1980s. The continuous migration and the subsequent housing demand however led to first land speculations and thus large areas of unbuilt land, which caused a fragmentation of settlement areas, particularly along the urban periphery (Wiedmann, 2012, p. 24). The rising land prices in well accessible areas, particularly in the North of cities and along shorelines in proximity to urban centers led to two phenomena: The rising urban density in transition zones between downtown and industrial areas as well as the development of residential areas far from urban centers (Wiedmann, Salama and Thierstein, 2012, p. 42).

Since the 1990s a new urban development vision was introduced in Gulf cities based on the strategy to establish well connected hub cities between international markets. In addition to new airports and ports, new economies, such as tourism, were used as important catalysts in accelerating investment dynamics (Schmid, 2009). The subsequent construction boom has transformed Gulf cities from their rather simplistic structure based on mixed-use downtown areas surrounded by a low-rise urban periphery towards a more complex and diverse urban landscape (Scharfenort, 2009) (Figure 1). The main drivers of this spatial transformation were large-scale developers and their holdings that initiated mega projects covering vast areas towards inland as well as on reclaimed land along the coast (Salama and Wiedmann, 2013).

Fig. 1. The urban transformation from Gulf cities: The shift of high urban densities towards the urban periphery (Source: Authors). 
In 1999 the first freehold property project, known as Emirates Hills, in Dubai marked a new era in housing development, driven by investment interests rather than demanddriven dynamics. Davidson (2009, p. 128) states that the exponential population increase has been a direct consequence of expanding service sectors associated with real-estate and construction industries. The newly emerging medium to high income guest workers and their families became important factors within the local housing markets leading to housing demand and a continuous increase of rental rates. Consequently, the lack of affordable housing for medium income groups began to challenge urban governance (Ernest \& Young, 2013).

In the case of low income laborers employers have been usually obliged to provide accommodation, which has led to the phenomenon of large-scale labor camps in the outskirts and in proximity to industrial areas leading to widespread international criticism on social standards in Gulf States (Gardner, 2011). Furthermore, a large quantity of guest workers engaged in the retail sector and other low income service sectors usually reside without their families in Gulf cities and are forced to share apartments in order to afford the rising rental prices. This has led to overcrowded downtown districts and decreasing living standards in many areas (Beaugrand, 2014).

In the Emirate of Dubai, a large percentage of medium income groups have decided to move to neighboring cities in the Northern Emirates in order to find affordable housing leading to challenging traffic congestion (Lipps, 2008). The move of affordable housing towards the urban periphery is one of the main contemporary development tendencies, which has been further enforced by the rather recent phenomenon of large scale mega projects in old city cores. The lack of distinctive urban identities led to major restoration and revitalization investments followed by cultural landmark projects, such as museums, as well as the interest of the private sector to develop real-estate for the upper markets (Wiedmann, Mirincheva and Salama, 2013). These investments and public development strategies led to the demolition and replacement of various residential areas and thus a severe affordable housing deficit for lower income groups. The relocated social groups mainly consist of migrants from the Middle Eastern region as well as the Indian subcontinent, who often resided for generations in these inner city neighborhoods (Law and Underwood, 2012).

The consequence of recent investment dynamics focusing on freehold properties as well as revitalization strategies have been various large scale mass housing projects based on certain principles of public-private partnerships, such as the provision of land and infrastructure by governments. Therefore, one of the main objectives of this paper is an attempt to introduce the various spatial implications as well as current challenges by analyzing two large-scale projects in the cities of Doha and Dubai.

\section{THE ASSESSMENT FRAMEWORK}

Based on the triad of sustainability (environment, economy and social equity) a framework can be introduced based on eighteen key impact factors of new affordable 
housing projects in generating sustainable urban structures (Table 1). Factors can be summed up underlying the three categories of sustainability: From an environmental impact perspective new projects need to be located in highly accessible areas with a sufficient level of land-use integration as well as balanced urban densities. Furthermore, the spatial layout needs to encourage walking and the integration of new technologies can reduce the waste of energy and water. From an economic impact perspective, a new project needs to become a local center attracting a wide variety of businesses as well as investment opportunities. The spatial layout is important to permit and enhance diverse economic activities. From a social impact perspective key parameters apply, including the integration of various social groups and the role of the new projects as important landmarks for an emerging community with a high diversity of lifestyle choices (Salama, 2006 and 2011).

Table 1. The eighteen key parameters to improve the impact of affordable mega projects on sustainability (Source: Authors).

\begin{tabular}{|l|l|l|}
\hline \multicolumn{1}{|c|}{ Environmental Impact } & \multicolumn{1}{|c|}{ Economic Impact } & \multicolumn{1}{c|}{ Social Impact } \\
\hline $\begin{array}{l}\text { Proximity to main urban } \\
\text { centers }\end{array}$ & $\begin{array}{l}\text { Role as major local } \\
\text { service center }\end{array}$ & $\begin{array}{l}\text { Role as a new landmark } \\
\text { and cultural center }\end{array}$ \\
\hline $\begin{array}{l}\text { Enabling short ways to } \\
\text { services }\end{array}$ & $\begin{array}{l}\text { Flexible demand-driven } \\
\text { development }\end{array}$ & $\begin{array}{l}\text { Integration of various } \\
\text { social groups }\end{array}$ \\
\hline $\begin{array}{l}\text { Integration of green } \\
\text { areas }\end{array}$ & $\begin{array}{l}\text { Integration of business } \\
\text { opportunities }\end{array}$ & $\begin{array}{l}\text { Integration of social } \\
\text { services }\end{array}$ \\
\hline $\begin{array}{l}\text { Well distributed urban } \\
\text { densities }\end{array}$ & $\begin{array}{l}\text { Sufficient urban } \\
\text { densities }\end{array}$ & Healthy urban densities \\
\hline $\begin{array}{l}\text { Integration of new } \\
\text { ecological technologies }\end{array}$ & $\begin{array}{l}\text { Various investment } \\
\text { opportunities }\end{array}$ & $\begin{array}{l}\text { Integration of various } \\
\text { lifestyle choices }\end{array}$ \\
\hline $\begin{array}{l}\text { Optimized spatial layout } \\
\text { to encourage walking }\end{array}$ & $\begin{array}{l}\text { Optimized spatial layout } \\
\text { to encourage business }\end{array}$ & $\begin{array}{l}\text { Optimized spatial layout } \\
\text { for safety and comfort }\end{array}$ \\
\hline
\end{tabular}

The main aim of the proposed framework is to enable a preliminary assessment of large-scale affordable housing projects without the excessive collection of data. The minimum data required for this assessment framework includes: The general distances of the new projects to key locations, the general land-use distribution and the maximum 
population as well as the general measurements of the development area in addition to a review of recent property prices and rental rates. This framework can be thus applied as a focused pre-assessment of the various parameters needed for a more sustainable urban development.

\section{THE CASES OF BARWA CITY IN DOHA AND DUBAI INTERNATIONAL CITY}

The methodological approach for assessing the two cases follows the preceding framework. The data collected includes the evaluation of official planning reports including demographic and socio-economic studies from Qatar's Ministry of Municipality and Urban Planning and Dubai Municipality. Therefore, planning departments and their housing experts were visited in both cities as part of the information gathering procedures. In addition, local real-estate newspaper articles were evaluated in order to review past and present development dynamics in both case studies. Furthermore, property and rental prices were reviewed by evaluating property websites and official statistics in order to assess recent market tendencies. Based on the authors' continuous research in the region since 2011, various field studies were carried out to explore contemporary spatial implications of the selected case studies.

Notably, both case studies were selected due to their size and major role in recent dynamics of affordable housing development. On one hand, Barwa is the largest realestate developer in Qatar and was founded in 2005 on the basis of large public shares. $45 \%$ of shares are therefore owned by Qatari Diar, which belongs to the Qatar Investment Authority (Barwa, 2016). The main objective of Barwa is to drive the local real-estate market and to integrate new dynamics in accordance to the overall vision to establish a diversified economy. On the other hand, the Dubai International City's developer is Nakheel, a company that was transferred from a semi-public holding, known as Dubai World, to Dubai's government due to financial restructuring in 2011 (Fitch, 2011).

\section{Environmental Impact}

Both projects are located in similar locations in proximity to industrial areas in the South and with distances of about 10 to 15 kilometers from main business centers and international airports (Figure 2) in both cities. Barwa City is located in the Mesaimeer district, which has become a main focal point of large scale developments in spite of its industrial surroundings. The International City in Dubai is located in the Al Warsan district, which is in proximity to the Southern end of the Dubai Creek. Both projects are located in average distances to main urban centers leading to travel times of at least thirty minutes by car. While the location of both developments is in a sufficient distance to main urban centers, the development sites hardly integrate a big variety of services. Thus, schools can only be accessed by car in a distance of two or three kilometers where walking is not possible due to climatic conditions. 
Fig. 2. The spatial location of Dubai International City (left) and Barwa City (right) and their general distances to key places (Source: Authors and Google Earth).

Today, around 60,000 people reside in Dubai International City. Once the project is completed it will cover an area of more than 800 hectares and offer housing units for a maximum of 120,000 residents in 413 buildings with more than 23,000 rental units (International City Dubai, 2016). Thus, a rather high urban density of more than 100 inhabitants per hectare will be achieved. In comparison Barwa City's first phase has been completed including 128 residential buildings on around 270 hectares with a builtup area of 1.3 million square meters offering 5,968 apartments for up 25,000 residents (Waseef, 2016) (Figure 3). The expected overall urban density is slightly less than 100 inhabitants per hectare, but in clear contrast to its desert surroundings. The medium urban densities are distributed rather evenly due to similar typologies enabling an efficient supply of infrastructure and the opportunity to establish a pedestrian-friendly environment. While a district cooling plant is integrated in the case of Barwa, no distinctive modern technologies have been introduced in Dubai International City to reduce energy waste. Both developments currently lack sufficient access to public transportation.

Fig. 3. The general spatial layout of Barwa City (Source: Google Earth).

The spatial layout of Barwa City is dominated by the orthogonal road grid. While pedestrian movement is encouraged in the central spine between the two main service centers, the overall surroundings are less inviting to walk due to the general distances and the mainly residential land-use. In comparison International City lacks a clear emphasis on a main corridor and provides an evenly distributed mixed land-use. Due to the international financial crisis in 2008 a large central area of 240 hectares, known as Forbidden City, has not yet been developed, which has led to a vacant core and a fragmented structure (Construction Week, 2009) (Figure 4).

Fig. 4. The current development stage of Dubai International City (Source: Google Earth).

While on the one hand the mixed land-use in International City enables a greater incentive to walk to certain near-by services, the lack of a clear main corridor and center has however led to a scattered distribution and far distances in many locations. Both spatial layouts thus lack a clear emphasis on walkability by developing main activity corridors and linking neighborhoods. Sports grounds and green areas are integrated in both developments. While the central green corridor in Barwa City is linking all major public areas and services, the International City is lacking cohesive green spaces due to its ornamental grid. 
It can be argued that Barwa City in Doha and Dubai International City are rather equal in the case of their current environmental impact. The similar locations and the similar urban densities have led to very comparable conditions. While Barwa City is more advanced due to improved construction standards and district cooling as well as a cohesive public realm in its core, Dubai International City provides certain opportunities to be developed into a highly mixed-use urban district with short walking distances.

\section{Economic Impact}

In Barwa City seventeen commercial and amenities buildings have been built including a shopping center and a medical center. The residential buildings are grouped in orthogonal clusters around two zones for amenities. The orthogonal grid of Barwa City permits a quick understanding of the general spatial layout, but it suffers from the rigid symmetrical repetition leading to many similar urban spaces. Additionally, Barwa City lacks adequate street life, which is mainly rooted in missing commercial activities along roads (Figure 5 and 6 ). The development of shopping centers instead of commercial pedestrian environment has led to a suburban setting. Barwa City is thus mainly perceived as dormitory settlement instead of an emerging center at Doha's periphery.

\section{Fig. 5. Typical residential buildings in Barwa City (Source: Authors).}

Fig. 6. A deserted public space in Barwa City (Source: Authors).

In spite of integrated commercial use in most ground floors - 5,000 retail units according to Nakheel (2016) - Dubai International City has not yet emerged to a major local center attracting residents from neighboring districts. While the themed architectural design and typological variety in Dubai International City have led to a higher spatial diversity than in Barwa City, the ornamental layout and the limited entrances have weakened the general orientation. Today, many shops are vacant and the entire development is suffering from a missing diversity of income groups, which is the basis for any enhanced stimulation of commercial activities. The top-down development of both mass housing projects following strict master plans has resulted in a lack of demand-driven dynamics and a greater variety of housing typologies attracting a more diversity of tenants as well as buyers of real-estate.

Both projects offer sufficient urban densities to attract businesses and thus economic activities. While Dubai International City is currently providing various business opportunities depending on the general socio-economic context, Barwa City has been planned as a mega compound with no integration of small business initiatives to benefit from the rather high urban densities. Residents will thus rely on shopping malls and mega marts instead of funding small businesses in their neighborhood. 


\section{Social Impact}

Based on their size both developments should have the potential to become main landmarks and cultural centers attracting various human interactions. The design as developments with limited public access along the urban periphery and the missing integration of important public transportation junctions and associated public realm have however resulted in gated-like urban environments rather than new urban centers with their own distinctive place identities. Thus, the opportunity to use these mass housing projects as catalysts igniting future upgrading processes and polycentric urban development is rather limited.

Both projects are currently representing the complex spectrum of affordable housing concerns in Gulf cities. While rental prices have been increased dramatically in Barwa City challenging lower medium income tenants, the global financial crisis and the subsequent drop of real-estate prices in Dubai led to another phenomenon: The move of very low income groups to the International City.

The total of 5,968 apartments in Barwa City includes 1,024 studios, 1,056 two-bedroom and 3,888 three-bedroom apartments. While studios have a size of 31 square meters, the two-bedroom apartments reach 100 and the three-bedroom apartments 121 and 135 square meters (Waseef, 2012, p. 8). Based on average rental prices in 2013 a twobedroom apartment in Barwa City was rented between QR 6,500 to QR 7,000 per month (Kovessy, 2015). In the beginning of 2015 the rental rates were increased between QR 2,000 and QR 3,000 per month. This rental price increase of $37 \%$ has been mainly an outcome of the urgent need for housing under QR 10,000 per month, which is the result of continuous migration as well as rising rental prices in Doha's Northern and Western districts leading to the move of medium income groups. Further factors have been the high urban density and traffic congestion in inner city districts as well as the generally high built quality of Barwa City in spite of its monotonous urban and architectural design and the still missing facilities (Scott, 2014).

According to various property online platforms for the UAE a two-bedroom apartment with 130 square meters is currently rented for less than AED 6,000 per month in Nakheel's International City. In 2007 however apartments were rented for more than AED 8,000 per month. Since then the international financial crisis rental prices have significantly dropped in areas located in the urban periphery of Dubai (Kumar, 2014). Furthermore, the move of particularly Chinese migrants due to the Chinese investment in Dragon Mart project has led to a major demographic change. In addition, the proximity of the sewage plant has created stench issues in various areas (Al Serkal, 2013). Since Nakheel has faced major financial problems after 2009 the developer has dropped controls and checks over the city's security leading to an enhanced crime rate (Al Najami, 2009).

While most residential buildings in Barwa City vary from five to six floors leading to a rather uniform rectangular development surrounded by vacant land, there is a greater diversity of building heights up to eleven floors in the case of Nakheel's International City. In Dubai International City a multitude of roads and spaces can be found, which 
are hardly watched by residents. This has led to major urban safety concerns (Figure 7 and 8). The limited integration of social services, such as schools and a variety of leisure spaces and facilities, has led to a rather reduced compatibility to host a diversity of social groups and their lifestyles in both developments.

Fig. 7. A cluster of Dubai International City and spaces with hardly any visitor movements (yellow) (Source: Google Earth).

Fig. 8. The built environment in the back of main roads in Dubai International City (Source: Authors).

\section{CONCLUSION}

The current development tendencies display the challenging and rapidly changing environment, in which both projects have been conceived and built. Neither developers nor decision-makers can currently predict the role of these projects in the future, but as uniform mass housing projects the entire development sites will be affected by newly emerging conditions. Thus, overnight both city projects have witnessed a change of their roles within the local housing markets. While the upgrading can be mainly considered as a temporary effect of local housing shortage, the downgrading has to be seen as a severe threat due to the move of private sector investment. Dubai International City cannot be considered a contemporary case of a failed medium income city. At the same time, an emerging ghetto such as Barwa City cannot be identified as a complete failure to offer housing alternatives for medium income groups due to the recent increase of rental prices.

Based on the sustainability framework introduced earlier both projects can be compared by assessing each of the eighteen points. The introduction of an assessment scale ( 1 to 10) permits an illustration of the differing results in both cases (Table 2). While Dubai International City has the potential to become a main mixed-use district offering microeconomic development dynamics, Barwa City has a superior built environment of certain ecological and social concerns but with the higher potential to accommodate various income groups in future. The framework is thus a preliminary tool to underscore key differences and can support future planning and design guidance.

Table 2. The rating of each criteria for both city projects by applying an assessment scale from 1 to 10 . (Source: Authors). 


\begin{tabular}{|c|c|c|c|c|c|c|c|c|}
\hline Environmental Impact & 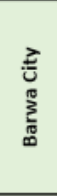 & 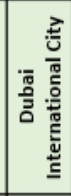 & Economic Impact & 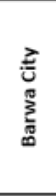 & 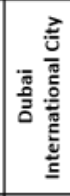 & Social Impact & 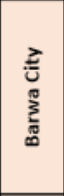 & 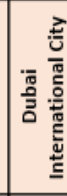 \\
\hline $\begin{array}{l}\text { Proximity to main } \\
\text { urban centers }\end{array}$ & 6 & 6 & $\begin{array}{l}\text { Role as major local } \\
\text { service center }\end{array}$ & 4 & 3 & $\begin{array}{l}\text { Role as a new } \\
\text { landmark and } \\
\text { cultural center }\end{array}$ & 1 & 1 \\
\hline $\begin{array}{l}\text { Enabling short ways to } \\
\text { services }\end{array}$ & 2 & 2 & $\begin{array}{l}\text { Flexible demand- } \\
\text { driven development }\end{array}$ & 1 & 1 & $\begin{array}{l}\text { Integration of various } \\
\text { social groups }\end{array}$ & 3 & 2 \\
\hline $\begin{array}{l}\text { Integration of green } \\
\text { areas }\end{array}$ & 7 & 6 & $\begin{array}{l}\text { Integration of } \\
\text { business } \\
\text { opportunities }\end{array}$ & 2 & 6 & $\begin{array}{l}\text { Integration of social } \\
\text { services }\end{array}$ & 4 & 4 \\
\hline $\begin{array}{l}\text { Well distributed urban } \\
\text { densities }\end{array}$ & 7 & 8 & $\begin{array}{l}\text { Sufficient urban } \\
\text { densities }\end{array}$ & 7 & 7 & $\begin{array}{l}\text { Healthy urban } \\
\text { densities }\end{array}$ & 7 & 7 \\
\hline $\begin{array}{l}\text { Integration of new } \\
\text { ecological technologies }\end{array}$ & 6 & 3 & $\begin{array}{l}\text { Various investment } \\
\text { opportunities }\end{array}$ & 3 & 4 & $\begin{array}{l}\text { Integration of various } \\
\text { lifestyle choices }\end{array}$ & 2 & 2 \\
\hline $\begin{array}{l}\text { Optimized spatial } \\
\text { layout to encourage } \\
\text { walking }\end{array}$ & 5 & 6 & $\begin{array}{l}\text { Optimized spatial } \\
\text { layout to encourage } \\
\text { business }\end{array}$ & 3 & 6 & $\begin{array}{l}\text { Optimized spatial } \\
\text { layout for safety and } \\
\text { comfort }\end{array}$ & 3 & 2 \\
\hline Total: & 33 & 31 & Total: & 20 & 27 & Total: & 20 & 18 \\
\hline
\end{tabular}

Affordable housing will remain one of the key challenges of urban planning to establish sustainable Gulf cities. The new mega projects have led to new dormitory settlements and an enhanced fragmentation of urban landscapes. Various factors endanger their role to become long-term solutions for affordable housing. Concomitantly, the authors argue that they have contributed to filter and disintegrate a crucial part of the urban population and thus to enhance social segregation. In generic terms, affordable housing strategies can play a crucial role in enabling sustainable cities. The widespread integration of affordable housing in a great variety of districts has proven to be less problematic long-term than mass housing projects covering large areas with monotonous building typologies on the peripheries of gulf cities. This integration however needs an advanced coordination and the establishment of strict regulations within the clear sustainable development frameworks.

\section{ACKNOWLEDGEMENTS}

This paper is developed as part of a comprehensive funded research project of the National Priorities Research Program, QNRF-Qatar National Research Fund (NPRP 7 960 - 5 - 135), entitled: Investigating Housing Typologies in Multicultural Societies of the Gulf Region, and is undertaken as part of research collaboration between University of Strathclyde, Glasgow, UK and Qatar University, Doha, Qatar. 


\section{REFERENCES}

AL BUAINAIN, F. 1999. Urbanization in Qatar: A Study of the Residential and Commercial Land Development in Doha City, 1970 - 1997. University of Salford, Salford.

AL HATHLOUL, S. and MUGHAL, M. A. 2004. Urban Growth Management. The Saudi Experience, in Habitat International, 28(4), 609-623.

AL NAJAMI, S. 2009. Reader Helps Police to Bust Brothel in International City. Available at: http://gulfnews.com/news/uae/crime/reader-helps-police-to-bust-brothel-in-international-city1.531990 [accessed: 14 February 2016].

AL SERKAL, M. 2013. International City Stench Concerns Waved Away, in Gulf News. Available at: http://gulfnews.com/news/uae/environment/international-city-stench-concernswaved-away-1.1149641 [accessed: 14 February 2016].

BARWA 2016. Share Capital Information. Available at: http://www.barwa.com.qa/sites/English/InvestorRelations/SitePages/Home.aspx [accessed: 14 February 2016].

BEAUGRAND, C. 2014. Urban Margins in Kuwait and Bahrain: Decay, Dispossession and Politicization, in City: Analysis of Urban Trends, Culture, Theory, Policy, Action, 18 (6), 735-745.

CONSTRUCTION WEEK 2009. Cancelled and Delayed UAE Projects. Available at: http://www.constructionweekonline.com/article-4360-cancelled-and-delayed-uae-projects--thefull-list/ [accessed: 14 February 2016].

DAVIDSON, C. 2009. Dubai: The Vulnerability of Success. Hurst C \& Co, New York.

ERNEST and YOUNG, 2013. The Growing Crisis of Affordable Housing in MENA. Available at: http://www.ey.com/Publication/vwLUAssets/The_growing_crisis_of_affordable_housing_in_ME NA/\$File/The_growing_crisis_of_affordable_housing_in_MENA.pdf [accessed: 14 February 2016].

FITCH, A. 2011. Dubai to Take Over Limitless and Nakheel. In: The National, July 7, 2011. Available at: http://www.thenational.ae/business/property/dubai-to-take-over-limitless-nakheel [accessed: 14 February 2016].

FLORIDA, R. 2002. The Rise of the Creative Class: And How It is Transforming Work, Leisure, Community and Everyday Life. Perseus Book Group, New York.

GARDNER, A. 2011. Gulf Migration and the Family, in: Journal of Arabian Studies. 1 (1), 3-25. HALL, P. 2002. Cities of Tomorrow (3rd ed.), Blackwell, Malden, Massachusetts.

HOWARD, E. 1902. Garden Cities of Tomorrow (2nd ed.), S. Sonnenschein \& Co, London. International City Dubai. 2016. Available at: http://www.internationalcity-dubai.com/ [accessed: 14 February 2016]. 
JACKSON, K. T. 1985. Crabgrass Frontier: The Suburbanization of the United States. Oxford University Press, New York.

KOVESSY, P. 2015. Some Residents of Qatar's Barwa City Lament Large Upcoming Rent Hike, in: Doha News. Available at: http://dohanews.co/residents-qatars-barwa-city-lamentlarge-upcoming-rent-hike/ [accessed: 14 February 2016].

KUMAR, A. 2014. Dubai Rents Fall for the First Time in Three Years, in: Gulf News. Available at: http://gulfnews.com/news/uae/dubai-rents-fall-for-the-first-time-in-three-years-1.1428349 [accessed: 14 February 2016].

LAW R. and UNDERWOOD, K. 2012. Msheireb Heart of Doha: An Alternative Approach to Urbanism in the Gulf Region, in International Journal of Islamic Architecture, 1 (1), 131-147.

LEY, D. 1994. Gentrification and the Politics of the New Middle Class, in Environment and Planning, Society and Space, 12, 53-74.

LE CORBUSIER 1967. The Radiant City: Elements of a Doctrine of Urbanism to be used as the Basis of Our Machine-age Civilization. Faber \& Faber, London.

LIPPS, W. 2008. Der Immobilienmarkt in Dubai, in Blum, E. und P. Neitzke (eds.) 2009. Dubai: Stadt aus dem Nichts. Bauwelt Fundamente, Band 143. Berlin. 212-226.

LUND, B. 1996. Housing Problems and Housing Policy, Longman, New York.

NAKHEEL 2016. Dubai International City. Available at:

http://www.nakheel.com/en/leasing/international-city [accessed: 14 February 2016].

NEWMAN, P. W. and KENWORTHY, J. R. 1989. Cities and Automobile Dependence: An International Sourcebook. Gower, Aldershot.

NIGHTINGALE, C. H. 2012. Segregation: A Global History of Divided Cities. The University of Chicago Press, Chicago.

SALAMA, A. M. 2006, A Lifestyle Theories Approach for Affordable Housing Research in Saudi Arabia, in Emirates Journal for Engineering Research, Vol 11 (1), 67-76.

SALAMA, A. M. 2011, Trans-disciplinary Knowledge for Affordable Housing. In Open House International, Vol 36 (3), 7-15.

SALAMA, A. M. and WIEDMANN, F. 2013. Demystifying Doha: On Architecture and Urbanism in an Emerging City. Ashgate Publishing Limited, Surrey.

SASSEN, S. 1994. Cities in a World Economy. Pine Forge Press, Thousand Oaks.

SCHARFENORT, N. 2009. Auf Sand Gebaut, in Blum, E. und P. Neitzke (eds.) 2009. Dubai: Stadt aus dem Nichts. Bauwelt Fundamente, Band 143. Berlin. 31-54.

SCHMID, H. 2009. Economy of Fascination: Dubai and Las Vegas as Themed Urban Landscapes. Borntraeger, Stuttgart. 
SCHOLZ, F. 1999. Die Kleinen Golfstaaten. 2nd Edition. Justus Perthes Verlag Gotha GmbH, Gotha.

SCOTT, V. 2014. Barwa City Residents Complain about Lack of Facilities. In: Doha News. Available at: http://dohanews.co/barwa-city-residents-complain-high-utility-bills-lack-facilities/ [accessed: 14 February 2016].

WASEEF 2012. Barwa City Residential Tenant Manual. Available at:

http://www.waseef.qa/en/wp-content/uploads/2013/05/Tenant-Manual-Barwa-City-Final.pdf [accessed: 14 February 2016].

WASEEF 2016. Barwa City. Available at: https://www.waseef.qa/en/barwa-city/ [accessed: 14 February 2016].

WIEDMANN, F. 2012. Post-oil Urbanism in the Gulf: New Evolutions in Governance and the Impact on Urban Morphologies. Südwestdeutscher Verlag für Hochschulschriften, Stuttgart.

WIEDMANN, F., MIRINCHEVA, V., \& SALAMA, A. M. 2013. Urban Reconfiguration and Revitalization: Public Mega Projects in Doha's Historic Centre. Open House International, 38(4), 27-36.

WIEDMANN, F., SALAMA, A.M. and THIERSTEIN, A. 2012. Urban Evolution of the City of Doha: An Investigation into the Impact of Economic Transformations on Urban Structures, in METU Journal of the Faculty of Architecture. 29(2), 35-61.

Authors

\section{Dr. Florian Wiedmann}

Cluster for Research in Architecture and Urbanism of Cities in the Global South (CRAUCGS)

Department of Architecture,

University of Strathclyde

Glasgow G1 1XJ, United Kingdom

florian.wiedmann@strath.ac.uk

\section{Professor Ashraf M. Salama}

Cluster for Research in Architecture and Urbanism of Cities in the Global South (CRAUCGS)

Department of Architecture

University of Strathclyde,

Glasgow G1 1XJ, United Kingdom

ashraf.salama@strath.ac.uk

\section{Dr. Hatem G. Ibrahim}

Department of Architecture and Urban Planning

College of Engineering

Qatar University, Doha, Qatar

hatem_ibrahim@qu.edu.qa 